\title{
Epigenetic based synthetic lethal strategies in human cancers
}

Aiai Gao ${ }^{1}$ and Mingzhou Guo ${ }^{1,2,3^{*}}$ (D)

\begin{abstract}
Over the past decades, it is recognized that loss of DNA damage repair (DDR) pathways is an early and frequent event in tumorigenesis, occurring in 40-50\% of many cancer types. The basis of synthetic lethality in cancer therapy is DDR deficient cancers dependent on backup DNA repair pathways. In cancer, the concept of synthetic lethality has been extended to pairs of genes, in which inactivation of one by deletion or mutation and pharmacological inhibition of the other leads to death of cancer cells whereas normal cells are spared the effect of the drug. The paradigm study is to induce cell death by inhibiting PARP in BRCA1/2 defective cells. Since the successful application of PARP inhibitor, a growing number of developed DDR inhibitors are ongoing in preclinical and clinical testing, including ATM, ATR, CHK1/2 and WEE1 inhibitors. Combination of PARP inhibitors and other DDR inhibitors, or combination of multiple components of the same pathway may have great potential synthetic lethality efficiency. As epigenetics joins Knudson's two hit theory, silencing of DDR genes by aberrant epigenetic changes provide new opportunities for synthetic lethal therapy in cancer. Understanding the causative epigenetic changes of loss-of-function has led to the development of novel therapeutic agents in cancer. DDR and related genes were found frequently methylated in human cancers, including BRCA1/2, MGMT, WRN, MLH1, CHFR, P16 and APC. Both genetic and epigenetic alterations may serve as synthetic lethal therapeutic markers.
\end{abstract}

Keywords: DNA damage repair, Synthetic lethality, Epigenetics, BRCA1/2, PARP inhibitor

\section{Introduction}

The integrity of DNA is continually challenged by a variety of agents and processes that either alter the DNA sequence directly or cause mutation when DNA is suboptimally repaired. The ultraviolet component of sunlight can cause up to $1 \times 10^{5}$ DNA lesions per cell per day [1]. For example, ionizing radiation can cause singlestrand breaks (SSBs) and double-strand breaks (DSBs). If misrepaired, these breaks can induce mutations and lead to widespread structural rearrangement of the genome. DNA damage and mutation may be induced by environmental factors, including cigarette smoking, industrial

\footnotetext{
* Correspondence: mzguo@hotmail.com

'Department of Gastroenterology and Hepatology, Chinese PLA General Hospital, \#28 Fuxing Road, Beijing 100853, China

${ }^{2}$ Henan Key Laboratory for Esophageal Cancer Research, Zhengzhou University, 40 Daxue Road, Zhengzhou 450052, Henan, China

Full list of author information is available at the end of the article
}

chemicals, mustard gases and chemical therapeutic agents (such as cisplatin, mitomycin C). Reactive oxygen species (ROS) and other metabolites produced by endogenous processes can also induce DNA damaging [2]. According to the type of DNA lesion they process, DNA damage repair/response (DDR) may be divided into different pathways, which are functionally interwoven. Most of the subtle changes to DNA, such as oxidative lesions, alkylation products and SSBs, are repaired by base excision repair (BER) [3]. Whereas some of the bulkier single strand lesions that distort the DNA helical structure, such as those caused by ultraviolet light, are processed by nucleotide excision repair (NER) [4]. The major DDR mechanisms that cope with DSBs are homologous recombination repair (HR) and non-homologous end joining repair (NHEJ) [5]. HR is an error-free repair and mainly acts in the $S$ and G2 phase of cell cycle. The 
major components involved in HR include BRCA1, BRCA2, RAD51 and PALB2 genes. NHEJ occurs throughout the cell cycle. NHEJ mediates repair by directly ligating the end of a DSB together and may cause DNA deletion or mutation at the DSB site. Mismatch repair (MMR) deals primarily with dNTP misincorporation and formation of 'insertion and deletion' loops that form during DNA replication. Key proteins involved in this process including MLH1 and MSH2 [6, 7].

Defects in DDR can lead to an increase in genomic instability, which is one of carcinogenesis mechanisms in various cancers. However, DDR defects can be exploited in cancer therapy because excessive genomic instability itself can have lethal consequences by inducing deadly mutations, mitotic catastrophe, or chromothripsis [8]. Among the variety of types of DNA damage, the most deleterious is the DNA DSB. Cancer chemotherapeutic agents and radiotherapy exert their cytotoxic effects by inducing DNA DSBs [7]. DDR components are often defective in cancer, but the DDR comprises interacting/ crosstalking pathways, and defects in one can be compensated by alternative pathways. Such compensatory pathways obstruct effective cancer treatment [9]. For example, DSBs are predominantly repaired by the NHEJ pathway in G1 phase of cell cycle and by HR in S-G2 phases. Microhomology mediated end joining (MMEJ) is a "backup" DSB repair pathway in the event that NHEJ or HR are compromised. HR and MMEJ share the same substrate, a resected DSB that contains a $3^{\prime}$ singlestranded DNA (ssDNA) overhang bound by replication protein A (RPA). Thus, if HR is defect, MMEJ is the favored option to repair resected DSBs [10]. The concept of synthetic lethality was first described in fruit flies, when two single genetic defects, loss-of-function events, either alone had no effect on viability, but when combined resulted in lethality [11]. Over the past decades, it is recognized that loss of DNA repair pathways is an early and frequent event in tumorigenesis, occurring in 40-50\% of many cancer types [10]. However, DDR deficient cancers become critically dependent on backup DNA repair pathways, which present an "Achilles heel" that can be targeted to eliminate cancer cells. This is the basis of synthetic lethality. In 2005, two groups discovered a synthetic lethal interaction between PARP inhibition and mutations in BRCA1 or BRCA2 [12, 13]. The concept of "BRCAness" was originally meant that the phenotypes of some sporadic tumors share with "familial BRCA cancers". It was broadened by finding more functional "BRCAness" biomarkers [14]. In cancer, the concept of synthetic lethality has been extended to pairs of genes, in which inactivation of one by deletion or mutation and pharmacological inhibition of the other leads to death of cancer cells whereas normal cells are spared the effect of the drug [15]. With great understanding of the biology of DDR, more small molecules are being developed as new anticancer therapies by targeting DDR. There are approximately 450 genes coding for proteins involved in the DDR [16]. Many cancer type specific and pan-cancer targets were discovered through Proof-ofconcept classical synthetic lethal screening by small interfering RNA (siRNA) and CRISPR technology [15]. In addition, epigenetics plays an important role in silencing tumor suppressor gene expression, including DDR genes. Thus, numerous potential targets need to be identified in various cancers. This review mainly focused on applying "synthetic lethal" to human cancers with "BRCAness" and beyond caused by loss-of-function with defect of genetics or epigenetics.

\section{DNA damage checkpoints and DDR inhibitors}

DDR is composed of sensor proteins that detect and signal DNA damage to downstream effectors that, in turn, arrest cell cycle progression and promote repair. In response to DNA damage, cell cycle checkpoints can be activated in G1 phase, in S phase and at the G2/M transition [17-19]. Ataxia Telangiectasia Mutated (ATM) kinase is activated by DNA DSB and triggers the G1 checkpoint by phosphorylating and activating the checkpoint kinase 2 (Chk2) [20]. Chk2 inhibits Cdc25A preventing cells from proceeding into $S$ phase [21]. Of note, the G1 checkpoint is critically dependent on p53. The loss of G1 checkpoint control is almost ubiquitous in cancer, making cancer cells more reliant on the $S$ and G2/M checkpoints. When DNA damage occurs in $S$ phase, the intra $S$ phase checkpoint is activated to prevent further replication [22]. Ataxia Telangiectasia and Rad3 related (ATR) kinase is activated by DNA damage, through activating checkpoint kinase 1 (Chk1), and then induces Cdc25A proteosomal degradation to block further progression through S phase [23]. ATR and Chk1 also trigger the G2/M checkpoint, which prevents cells with damaged DNA from entering mitosis [24]. ATR inhibits cyclin $\mathrm{B} / \mathrm{Cdk} 1$ activation by stimulating the Wee1 (a Cdk1 inhibitory kinase) and inhibiting Cdc25c via Chk1 [17]. When cells with irreparable DNA damage are forced to enter into mitosis, they undergo permanent growth arrest or cell death through a so-called mitotic castrophe mechanism [25]. Forced entry of DNAdamaged cells into mitosis may provide a substantial increase in therapeutic efficacy.

A well-recognized sensor of DNA damage is the protein PARP, which is best known for its role in BER and repair of DNA SSBs. All PARP inhibitors (PARPi) interact with the binding site of the PARP enzyme cofactor, $\beta$-nicotinamide adenine dinucleotide $(\beta-\mathrm{NAD}+)$, in the catalytic domain of PARP1 and PARP2, including olaparib and niraparib [26]. Both BRCA1 and BRCA2 proteins are critical to the repair of DSBs by HR. Based on 
the synthetic lethal interaction between PARP inhibition and BRCA 1 or BRCA2 mutation, Farmer and Bryant developed a novel treatment strategy for BRCA-mutant tumors [12, 13]. Applying the concept of synthetic lethality, preclinical PARPi studies demonstrated that PARPi were able to selectively target $\mathrm{HR}$ deficient cells [27]. Data from phase II trials of women with BRCAmut ovarian cancer using olaparib at a dose of $400 \mathrm{mg}$ orally twice daily demonstrated RECIST (Response Evaluation Criteria in Solid Tumors) response rates of $30-41 \%$ [27, 28]. The phase II trial by Kaufman et al. demonstrated a $31 \%$ response rate and an additional $49 \%$ stable disease rate in their study subset of 193 women with platinumresistant ovarian cancer [29]. A phase II study of olaparib in patients with metastatic, hormone resistant prostate cancer showed promising results. Patients whose tumors harboring homologous deletions, mutations or both in DDR genes had a response rate of 33\% [30]. More specific and active PARPi are in developing and ongoing studies performing in breast, pancreatic and other cancers.

NER is a multistep DNA repair mechanism involving more than 30 different proteins to excise approximately 30 bases on a damaged DNA strand and to synthesize new DNA. One of the approaches aims at blocking the interaction between the different elements of the NER pathway, thus preventing the repair from being completed. The interaction of XPA with ERCC1 proved to be viable as druggable targets for cancer treatments. F06 inhibits NER by targeting XPF to reduce the interaction between ERCC1 and XPF [31]. ET-743, another NER inhibitor, was recently approved for the treatment of soft tissue sarcomas, ovarian cancer and is currently in clinical trials for the treatment of breast, prostate, and pediatric sarcomas [32]. Although NHEJ is considered to be the main pathway for repair of IR-induced DSBs, relatively little success has been observed with inhibitors targeting the main proteins in this pathway. Three DNA-PK related inhibitors MSC2490484A, CC-122, and CC-115 (DNA-PK and MTOR dual inhibitor) are currently being investigated in phase I clinical trial either for solid tumors, non-Hodgkin lymphoma, multiple myeloma or hematologic malignancies [33]. And a phase II clinical trial of CC-115 is onging in glioblastoma (NCT02977780). ATM is activated following DSBs and plays a major role in the DDR to DSBs caused by IR. ATM inhibitors were developed by different groups, including KU-55933, KU-60019 and KU-59403 [34-36]. ATR is primarily activated by SSBs and responds to DNA replication stress and is therefore active in the $\mathrm{S}$ and G2 phases of the cell cycle. Previous studies have demonstrated that alterations in canonical DDR/cell cycle checkpoint genes (ERCC1, XRCC1, CDC25A and ATM) have the potential to act as predictive biomarkers of single-agent ATRi sensitivity [37-39]. In preclinical studies, ATRi (VE-821) enhances the cytotoxic effects of a number of DNA damaging agents in tumor cells that have defects in the ATM/p53 pathway, including cisplatin, topotecan, and veliparib [40]. Although $>1000$ compounds have been evaluated as potential ATR inhibitors, only a few have exhibited "drug-like" properties. VX-970, VX-803, BAY1895344 and AZD6738 are currently in clinical studies [41]. Chk1 and Chk2 activation occurs through distinct mechanisms. Chk1 activation is primarily downstream of ATR in response to genotoxic insults. Chk2 is activated primarily by ATM in response to DSBs [42]. Chk1 is the primary effector of the intra-S and $\mathrm{G} 2 / \mathrm{M}$ phase checkpoints, whereas Chk2 plays an accessory role, exerting a partial influence on the intra- $S$ and G1/S checkpoints [43]. Chk1 exerts its function often through interacting with other proteins. Numerous proteins have been reported to interact with Chk1 [44]. In addition, crosstalk takes place between the ATRChk1 and ATM-Chk2 signaling cascades. Chk1 was initially thought to function as a tumor suppressor, and numerous efforts were made to look for Chk1 mutations in human tumors. However, so far no homozygous loss-offunction mutation of Chk1 has been detected in a wide range of human tumors $[45,46]$. Chk 1 inhibitors have been in development for two decades [47]. Chk1 inhibitor monotherapy often demonstrates limited efficacy and in general, must be combined with other agents. Evidence from the published clinical trials suggests that some Chk1 inhibitors can be administered safely, but when they are combined with traditional cytotoxic DNA damaging agents, the normal tissue toxicities outweigh the very modest gains in therapeutic efficacy. A variety of Chk1 and/or chk2 inhibitors are under active preclinical development, including EXEL-9844, CEP-3891, PD321852, Chir-124, CCT241533, LY2606368 [48]. The combination of Chk1 inhibitors with other signaling regulators may be a better therapeutic strategy $[49,50]$. In humans, the WEE kinase family consists of three kinases, including PKMYT1 (membrane-associated tyrosine- and threonine-specific cdc2-inhibitory kinase), WEE1 and WEE1B (WEE2) [51]. WEE1B expresses during early embryogenesis, and the expression is significantly reduced after fertilization [52]. PKMYT1 and WEE1 negatively regulate the cell cycle via the phosphorylation of CDK1. Both kinases are considered as main gatekeepers of the G2 cell-cycle checkpoint. Due to mutations in the p53 network, many cancer cells have defective G1 checkpoint mechanisms, which can result in increased DNA damage at the G2 checkpoint compared to normal cells. Cells with intact G1 checkpoint arrest, such as normal cells or cancer cells with intact p53 signaling, are less dependent on the G2 checkpoint arrest. Inhibition of PKMYT1 and WEE1 is particularly 
effective in cells with deficient p53 signaling [53, 54]. MK-1775 is the most potent and highly selective inhibitor of WEE1 and has recently reached phase I clinical trials [51]. Overexpression of POLOwas found in multiple HR-proficient tumor types such as lung, gastric and colorectal cancer, and was associated with adverse clinical outcomes [55]. The reason why POLOis upregulated and associated with poor outcomes in many tumors is not well understood. The possibility is that POLOrepairs spontaneous DNA damage present in cancer cells and therefore affords them a growth advantage [56]. POLOinhibitors could synergize with PARPi for the treatment of HR-deficient cancers [10].

\section{Genetic based synthetic lethal therapy in cancer}

Currently, most of targeting therapies in cancer are directly targeted at activated oncogenes or "gain of function" genetic aberrations, including gene mutation, amplification and fusion. Even though some of these strategies are very successful, such as EGFR and ALK inhibitors in lung cancer therapy, acquired resistance remains a major barrier to treatment [57]. Unfortunately, not all identified mutations or aberrant expressions can be directly targeted. Such as 'loss-of-function' or loss of expression by inactivating gene mutations are hard to restore activities pharmacologically, and less success has yet been achieved [58]. Notably, synthetic lethality strategy allows the therapeutic exploitation of non-druggable mutated tumor suppressor genes and directly difficultto-target (hard-druggable) oncogenes, via targeting their synthetic lethality partners [59]. Synthetic lethality approaches can achieve the effect of "target damage" by taking advantage of inherent differences between cancer cells and normal cells, which is not feasible with traditional chemotherapy [60]. Given that differences of genomic features between cancer cells and healthy cells, Hartwell was the first to use traditional genetic approaches, genomic information and model organisms for identifying and validating new targets for drugs that would selectively kill tumor cells with a particular molecular [26]. Subsequently, siRNA and CRISPR screenings have been developed to detect synthetic lethal gene pairs in human cells [15]. In recent years, Jerby-Arnon et al. proposed a computational and bioinformatics approach, named data mining synthetic lethality identification pipeline (DAISY), to identify genome-wide synthetic lethal interactions, by analyzing large volumes of cancer genomic data. They applied DAISY to identify all gene pairs that are likely to be synthetic lethal in cancer, resulting in a synthetic lethal network of 2077 genes and 2816 synthetic lethal interactions, and an synthetic dosage lethal (SDL) network of 3158 genes and 3635 SDL interactions [61]. With the help of these advanced screening tools, more novel candidate targets are expected to be discovered. The best-characterized synthetic lethality relationship is between BRCA1 or BRCA2 mutation and PARP inhibition. Several synthetic lethal combinations have been discovered, including Wee1 inhibitor (WEE1i) in p53-defecient cells, ATM inhibitor AZD0156 in conjunction with olaparib or irinotecan (a topoisomerase inhibitor) [62, 63]. It is well established that the genomes of all cancers carry somatic mutations, and advances in DNA sequencing technologies have made it possible to identify thousands of individual somatic mutations in a single cancer genome [64]. The mutation rate is not constant throughout the genome but differs $\sim 5$-fold, and a higher mutation rate is typically seen in late replicating and low transcribing genes [65]. Notably, $20 \%$ of tumors from a pan-cancer analysis identified subclonal mutations in the BRCA1/2 pathway [66]. A mutational signature associated with defective HR was first identified in BRCA1/2 germline mutant breast cancers [67], and later in ovarian, pancreatic, and gastric cancers [68-71]. As shown in Table 1, mutant DDR, cell cycle control and tumor suppressor genes are including RAD51, PALB2, P53, ATM, MGMT and Others [26]. Genes that result in a synergistic effect are commonly interpreted as working in compensatory pathways. The identification of such functional networks is particularly important for understanding cancer-related signaling pathways because the heterogeneity in the genetic background of cancers is often associated with the connected pathways that might provide multiple potential rewiring mechanisms.

\section{Epigenetic silencing of DDR and related genes in human cancers}

Accumulation of genetic and epigenetic alterations is regarded as a major factor for cancer initiation and progression, and aberrant epigenetic changes occur more frequently than gene mutations in human cancers [110, 111]. Epigenetic regulation of gene expression depends mainly on DNA methylation, histone modification and noncoding RNA. The regulators of "epigenetic machinery" are divided into "writers" (enzymes that establish DNA methylation or histone modification), "erasers" (proteins that remove these marks) and "readers" (proteins that bind to modifications and facilitate epigenetic effects) [112]. A lot of inhibitors, targeting "epigenetic machinery", are ongoing clinical trials [111]. Despite their promise, there are many challenges to be resolved for efficient use of epidrugs in the treatment of human cancer, including the lack of specificity of epidrugs, disappointing success in solid tumors and the acquisition of drug chemo-resistance leading to higher risk of tumor relapse. As lack of tumor specific histone modification detection markers, the efficiency of targeting histone modifier therapy remains very limited, even though a 
Table 1 Genetic defects of DDR in cancer and DDR inhibitors

\begin{tabular}{|c|c|c|c|c|}
\hline pathway & gene & genetic alterations & drugs & Refs \\
\hline \multirow[t]{5}{*}{ BER } & APE1 & SNP & & {$[72]$} \\
\hline & OGG1 & missense, frameshift, deletion, SNP & & [73] \\
\hline & Pol $\beta$ & frameshift, Splicing, missense & & {$[74]$} \\
\hline & XRCC1 & nonsense, missense, SNP & PARP, ATM, DNA-PKcs inhibitors & {$[75,76]$} \\
\hline & Neil1 & deletion, point mutation, SNP & & {$[77]$} \\
\hline \multirow[t]{8}{*}{ NER } & $X P C$ & SNP & & {$[78]$} \\
\hline & DDB1 & missense, splicing, deletion & & {$[79]$} \\
\hline & ERCC1 & SNP & ATR, CHEK1 inhibitors & {$[37,78]$} \\
\hline & ERCC2(XPD) & missense, SNP, homozygous deletion & & {$[80,81]$} \\
\hline & ERCC4(XPF) & missense & & {$[79]$} \\
\hline & ERCC5(XPG) & missense & & {$[79]$} \\
\hline & ERCC6 & missense, nonsense, splicing & & {$[79]$} \\
\hline & XPA & homozygous deletion, SNP & & {$[79,82]$} \\
\hline \multirow[t]{5}{*}{ MMR } & MLH1 & deletion, missense, nonsense, splicing & POLG, ATR inhibitor & {$[83,84]$} \\
\hline & $\mathrm{MSH} 2$ & deletion, nonsense, rearrangements & POLB inhibitor & [83-85] \\
\hline & MSH6 & point mutation & DHFR, POLB, POLG inhibitor & {$[85,86]$} \\
\hline & EPCAM & deletion & & {$[85]$} \\
\hline & PMS2 & point mutation & & {$[85]$} \\
\hline \multirow[t]{6}{*}{ HRR } & BRCA & truncating, missense, large rearrangements & $\begin{array}{l}\text { PARP, APE1, ATM, DNA-PKCS } \\
\text { inhibitors }\end{array}$ & [87-89] \\
\hline & $\begin{array}{l}\text { RAD51(RAD51B, RAD51C, } \\
\text { RAD51D) }\end{array}$ & $\begin{array}{l}\text { frameshift indels, splicing, nonsense, } \\
\text { missense. }\end{array}$ & PARP inhibitor & {$[90]$} \\
\hline & PALB2(FANCN) & frameshift, nonsense, splicing, deletion & PARP inhibitor & {$[91,92]$} \\
\hline & XRCC2 & SNP & & [93] \\
\hline & XRCC3 & SNP & & [93] \\
\hline & MSH3 & In-frame deletion, frameshift, missense & DNA-PKcs inhibitors & {$[94]$} \\
\hline FA pathway & FANC genes & missense, deletion, frameshift, SNP & PARP inhibitor & {$[95,96]$} \\
\hline \multirow[t]{2}{*}{ NHEJ } & XRCC4 & SNP & & [97] \\
\hline & LIG4 & SNP & PARP inhibitor & {$[98,99]$} \\
\hline \multirow[t]{2}{*}{$\begin{array}{l}\text { Cycle } \\
\text { checkpoints }\end{array}$} & ATR/Chk1 & SNP, insertion, deletion & APE1, Wee1, ATM, Chk1 inhibitor & $\begin{array}{l}{[43,88,100-} \\
103]\end{array}$ \\
\hline & ATM/Chk2 & SNP, nonsense, splicing, frameshift & $\begin{array}{l}\text { DNA-PKcs, PARP, pol } \theta \text {, MEK } \\
\text { inhibitors }\end{array}$ & {$[43,103,104]$} \\
\hline \multirow[t]{4}{*}{ Others } & CDK12 & deletion, missense, frameshift & PARP inhibitor & [105] \\
\hline & BAP1 & truncating, missense & PARP inhibitor & {$[106]$} \\
\hline & P53 & nonsense, missense & ATR, Chk inhibitor & {$[107,108]$} \\
\hline & PTEN & Mutation, deletion & PARP inhibitor & [109] \\
\hline
\end{tabular}

number of clinical trials are ongoing [111]. The best studied epigenetic modification is DNA methylation, as the nature of DNA is stable and the reliable detection technologies. Tumor suppressor gene promoter region methylation is frequently found in various human cancers. DNA methylation may serve as early detection, prognostic, chemo-radio-sensitive markers, and therapeutic targets [113]. Noncoding RNAs are functional RNA molecules that do not code for proteins. They are divided into different classes based on size, including siRNAs, miRNA, piRNAs and lncRNA [111]. Each class of RNA performs different endogenous functions, providing a variety of opportunities and challenges for drug discovery. New methods of design for the creation of artificial microRNAs as well as new systems of delivery by nanoparticles have been developed. However, the difficulties of a real tumor-specific delivery still represent an obstacle for the application of these methodologies in 
cancer therapy [114]. The field of lncRNAs is at its infancy. LncRNAs are poorly conserved across different species, therefore, the structural and functional information as well as the promising therapeutic strategies developed using in vitro and animal models may not be easily extended to human application [115]. The application of noncoding RNA in cancer synthetic lethality is very limited. Srinivasan et al. found that miR223-3p induced synthetic lethality in BRCA1- and BAP1-deficient malignancies by inhibiting alternative NHEJ signaling [116].

Understanding the causative epigenetic changes of loss-of-function has led to the development of novel therapeutic agents in cancer. The expression of DNA damage repair genes was found frequently silenced by promoter region methylation in various cancers. Silencing of DDR and cell cycle related genes provide opportunities for synthetic lethal therapeutic strategies in human cancers $[6,112]$. Defects of DDR may cause gene mutation and further induce carcinogenesis. Accumulation of DDR gene hypermethylation was found in the multistep of esophageal carcinogenesis and progression from normal tissue to different types of dysplasia and invasive cancer, including MGMT, MLH1, APC and BRCA1 [110]. Increased methylation of DDR and cell cycle related genes was also found progressively in the different types of pancreatic cancer from noninvasive intraductal papillary mucinous neoplasms (IPMN), IPMN with carcinoma in situ, IPMN with microinvasion and infiltrative IPMN with associated adenocarcinoma, including APC, hMLH1, MGMT, BRCA1, p14 and P16 [117]. These results suggest that synthetic lethality based on DDR methylation may apply to cancer prevention. DDR genes are more commonly found methylated in invasive cancers. Methylation of WRN was found in 37.9\% of colorectal cancer (CRC), 37.5\% of non-small cell lung cancer (NSCLC), $25 \%$ of gastric, $20 \%$ of prostate, $17.2 \%$ of breast, $12.5 \%$ of thyroid cancer, $23.7 \%$ of nonHodgkin lymphoma, $9.5 \%$ of acute lymphoblastic leukemia, $4.8 \%$ of acute myeloblastic leukemia, $33.3 \%$ of chondrosarcomas and $11.1 \%$ of osteosarcomas. WRN methylation is a sensitive marker for prediction of irinotecan in colorectal cancer [118]. Methylation of SLFN11 was found in $55.47 \%$ of CRC, $39 \%$ of papillary serous ovarian cancer, $29.9 \%$ of gastric cancer and $13.6 \%$ of NSCLCs. Methylation of SLFN11 reduced the sensitivity to cisplatin [119-121]. MLH1 was found methylated in $21.6 \%$ of gastric cancer patients and methylation of MLH1 was associated to oxaliplatin resistance [122]. XRCC1 was methylated in $76.4 \%$ of gastric cancer [123]. MED1, encoding a base excision repair enzyme, was methylated in $24 \%$ of CRC [124]. ERCC1 was methylated in $37.5 \%$ of gliomas, XPC was methylated in $34 \%$ of lung cancer and $32.45 \%$ of bladder cancers, XPG was methylated in $19 \%$ of ovarian cancers [125-128]. In NSCLCs,
BRCA1, BRCA2, and XRCC5 (ku80 encoding gene) was reported to be methylated in 30, 42 and 20\% [129]. Methylation of MGMT is the most studied DDR gene for chemo-sensitivity in various cancers $[6,130,131]$. GPX and GSTPi were also found frequently methylated in various tumors $[6,132]$.

CHFR, RASSF1A, P14, P15 and P16 genes are directly involved in cell cycle regulation and silenced by frequent methylation in different cancers. Other genes, including DACT2, SOX17, CDX2, NKD2, HIN1, IGFBPL1, TMEM176A, HOXD10, SFRP1, GATA4, GATA5, $\mathrm{CDH} 1, \mathrm{APC}, \mathrm{DACH} 1$, were reported frequently methylated and indirectly involved in cell cycle regulation through Wnt, PI3K-AKT, ERK, TGF-beta and other signaling pathways in different cancers [113, 133-140]. Beyond 'BRCAness', aberrant epigenetic changes in all these cell cycle regulators may provide new opportunities for synthetic lethal therapy in different cancers. CHFR is involved in G2/M checkpoint regulation, it is frequently methylated in esophageal cancer, gastric cancer and NSCLCs. Methylation of CHFR may serve as a docetaxel-sensitive marker [122, 141, 142]. RASSF1A inhibits G1-S transition and induces G2/M arrest in various cancers. Methylation of RASSF1A was frequently found in esophageal, gastric, lung and other cancers [143]. DACT2 was found frequently methylated in lung, esophageal, breast and other cancers. It may induce G1/ $\mathrm{S}$ or $\mathrm{G} 2 / \mathrm{M}$ checkpoint arrest in different cancers through Wnt signaling [144-147]. NKD2 was methylated in $53.2 \%$ of esophageal cancer and silencing of NKD2 activated Wnt signaling to promote G1/S transition [148]. Methylated DDR and related genes in cancers are listed in Table 2.

\section{The interplay of epigenetics and genetics in DNA damage repair genes}

Disruption of a key epigenetic regulator by mutation leads to an altered transcriptome, multiplying the effect of the single genetic alteration [165]. DNMT3A is recurrently mutated in acute myeloid leukemia (AML) and other myeloid malignancies [166, 167]. The majority of missense mutations impair the enzymatic activity of TET2, resulting in decreased $5 \mathrm{hmC}$ levels and aberrant DNA methylation [168]. Aberrant epigenetic changes may cause genetic abnormality. Epigenetic silencing of DNA repair genes such as MLH1, MGMT, BRCA1, FANCF, CHFR and SLFN11 can lead to gene mutations and genomic instability in cancer cells [112, 120, 169]. Lynch syndrome resulted from germline mutations in mismatch repair genes, primarily $\mathrm{MSH} 2$ and MLH1. Approximately $15 \%$ of sporadic colorectal cancer patients with microsatellite instability (MSI) were caused by epigenetic silencing of the MLH1 promoter region [151]. 
Table 2 Methylation of DDR and related genes in cancers

\begin{tabular}{|c|c|c|c|c|}
\hline Pathway & gene & tumor type & methylation frequency & refs \\
\hline \multirow[t]{20}{*}{ DDR } & BRCA1 & pancreatic & $46 \%$ & [149] \\
\hline & & NSCLC & $30 \%$ & [129] \\
\hline & & ESCC & $28 \%$ & [110] \\
\hline & & ovarian & $16.3 \%$ & [150] \\
\hline & BRCA2 & NSCLC & $42 \%$ & [129] \\
\hline & MGMT & gliomas & $40 \%$ & [130] \\
\hline & & $\mathrm{NSCLC}$ & $30 \%$ & [142] \\
\hline & & gastric & $9.8 \%$ & [122] \\
\hline & MLH1 & CRC & $38 \%$ & [151] \\
\hline & & ESCC & $33 \%$ & [110] \\
\hline & & gastric & $21.6 \%$ & [122] \\
\hline & MSH2 & HPNCC & $24 \%$ & [152] \\
\hline & & $\mathrm{HCC}$ & $24.6 \%$ & [153] \\
\hline & WRN & CRC & $37.9 \%$ & [118] \\
\hline & & NSCLC & $37.5 \%$ & [118] \\
\hline & & gastric & $25 \%$ & [118] \\
\hline & & prostate & $20 \%$ & [118] \\
\hline & FANCF & cervical & $30 \%$ & [154] \\
\hline & & ovarian & $21 \%$ & [154] \\
\hline & & breast & $17 \%$ & [154] \\
\hline \multirow[t]{24}{*}{ DDR related } & P16 & ESCC & $52 \%$ & [110] \\
\hline & & $\mathrm{NSCLC}$ & $29 \%$ & [142] \\
\hline & CHFR & ESCC & $45 \%$ & [141] \\
\hline & & gastric & $34.3 \%$ & [122] \\
\hline & & $\mathrm{NSCLC}$ & $10 \%$ & [142] \\
\hline & RASSF1A & gliomas & $79.4 \%$ & [155] \\
\hline & & cholangiocarcinoma & $65 \%$ & [156] \\
\hline & & gastric & $12.7 \%$ & [122] \\
\hline & SLFN11 & CRC & $55.47 \%$ & [120] \\
\hline & & papillary serous ovarian & $39 \%$ & [119] \\
\hline & & gastric & $29.9 \%$ & [121] \\
\hline & & NSCLCS. & $13.6 \%$ & [119] \\
\hline & DACT2 & ESCC & $69 \%$ & [145] \\
\hline & & gastric & $55.7 \%$ & [157] \\
\hline & & breast & $49.7 \%$ & [146] \\
\hline & & lung & $41 \%$ & [144] \\
\hline & NKD2 & ESCC & $53.2 \%$ & [148] \\
\hline & & gastric & $53.1 \%$ & [158] \\
\hline & & breast & $51.4 \%$ & [159] \\
\hline & $\mathrm{HIN}-1$ & ESCC & $50 \%$ & [160] \\
\hline & & NSCLC & $48 \%$ & [161] \\
\hline & $\mathrm{DACH} 1$ & gastric & $63.3 \%$ & [162] \\
\hline & & ESCC & $61.5 \%$ & [163] \\
\hline & & $\mathrm{HCC}$ & $42 \%$ & [164] \\
\hline
\end{tabular}

NSCLC Non-small cell lung cancer, ESCC Esophageal squamous cell carcinoma, CRC Colorectal cancer, HPNCC Hereditary non-polyposis, HCC

Hepatocellular carcinoma 
Methylation of MGMT in colorectal cancer is associated with G-to-A mutations in the KRAS gene [170]. It is clear that the cancer genome and epigenome influence each other in a multitude of ways. They offer complementary mechanisms to promote oncogenic transformation.

\section{Epigenetics joins Knudson's two hit theory}

Based upon observations on 48 cases of retinoblastoma and published reports, Knudson found that biallelic inactivation of the gatekeeper tumor suppressor gene is necessary for initiation of tumorigenesis. This finding is called 'Knudson's two hit theory', and this theory has served as an illuminating paradigm to guide the investigations of the countless tumors. In the other word, initiation of carcinogenesis needs 'loss-of-function' in both alleles of tumor suppressor [171, 172]. It is similar to gene mutations that epigenetic silencing of tumor suppressor genes may cause inactivation or 'loss-of-function' in these genes. Thus, epigenetics joins Knudson's two hit theory (Fig. 1). DDR and cell cycle regulator genes were found frequently methylated in human cancers. It is reasonable to apply the aberrant epigenetic changes to synthetic lethal therapy in human cancers (Fig. 2).

\section{Combined epigenetic and genetic disruption of gene expression in DDR for synthetic lethal therapy}

Mutational inactivation of gene expression or epigenetic silencing of gene expression may happen to two alleles by the same manner or by two different ways in each allele. For synthetic lethal therapeutic study, both genetic and epigenetic factors need to be included. Inactivation of MMR results in MSI. In population-based studies, the prevalence of MSI among CRCs is approximately $15 \%$. Germline MMR mutations that give rise to hereditary non-polyposis colorectal cancer (HPNCC) account for $3 \%$ of CRCs. In contrast to HPNCC, sporadic cancers are rarely found to have mutations in the MLH1 or $\mathrm{MSH} 2$ genes. Promoter region methylation accounts for 80-90\% of MLH1 biallelic inactivation in sporadic MSI$\mathrm{H}$ CRC [6, 173]. Heterozygous germline mutations in BRCA1/2 are responsible for a large fraction of hereditary breast cancers. While BRCA1/2 mutations affect a minority of breast cancer patients (fewer than 5\%). BRCA1 and BRCA2 were silenced by promoter methylation in 9 and $2 \%$ of sporadic breast cancer respectively $[6,174]$. Loss of heterozygosity (LOH) also joins the biallelic inactivation. For example, BRCA1 locus is lost by $\mathrm{LOH}$ in one allele and methylation is happened to

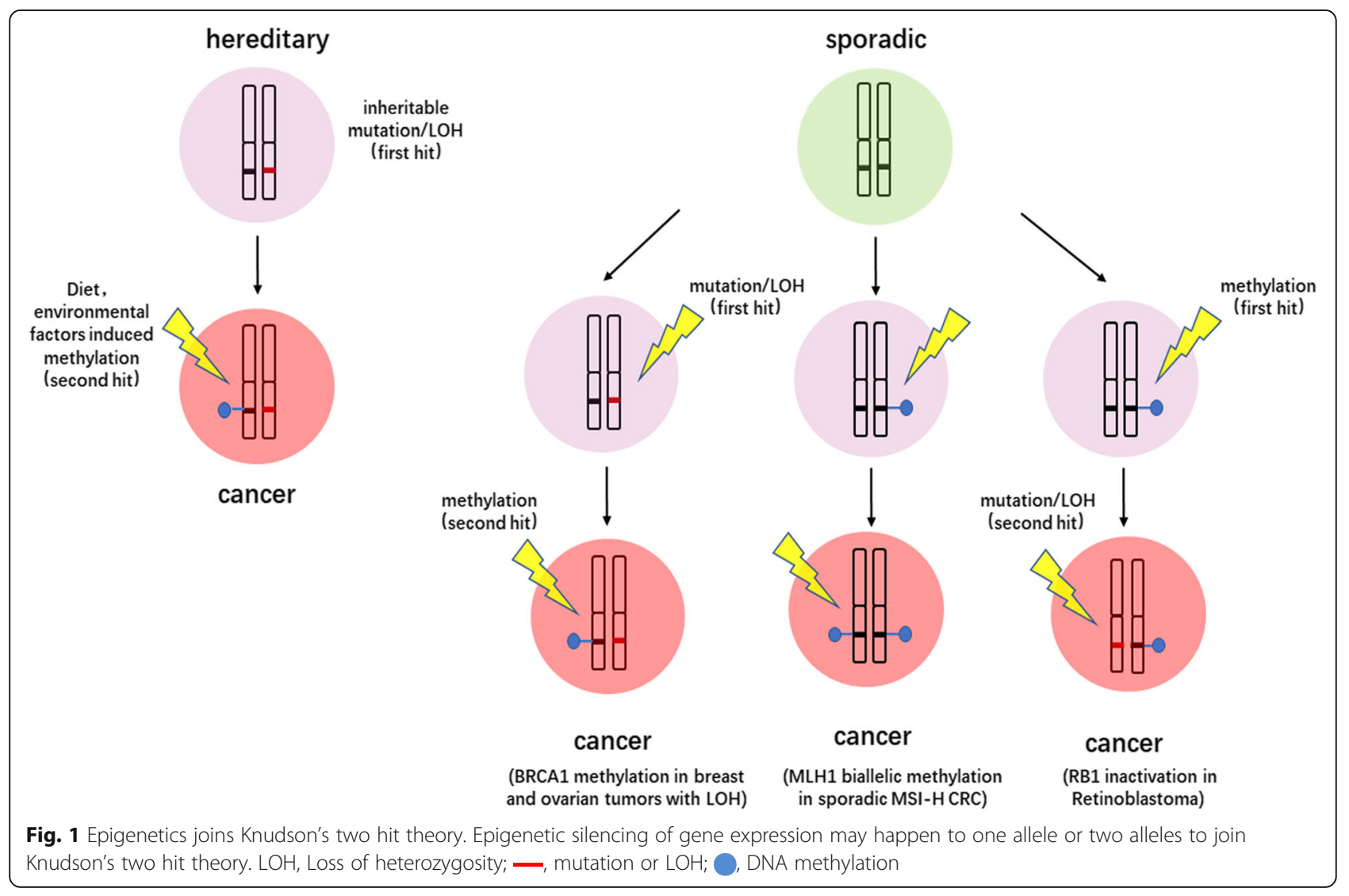



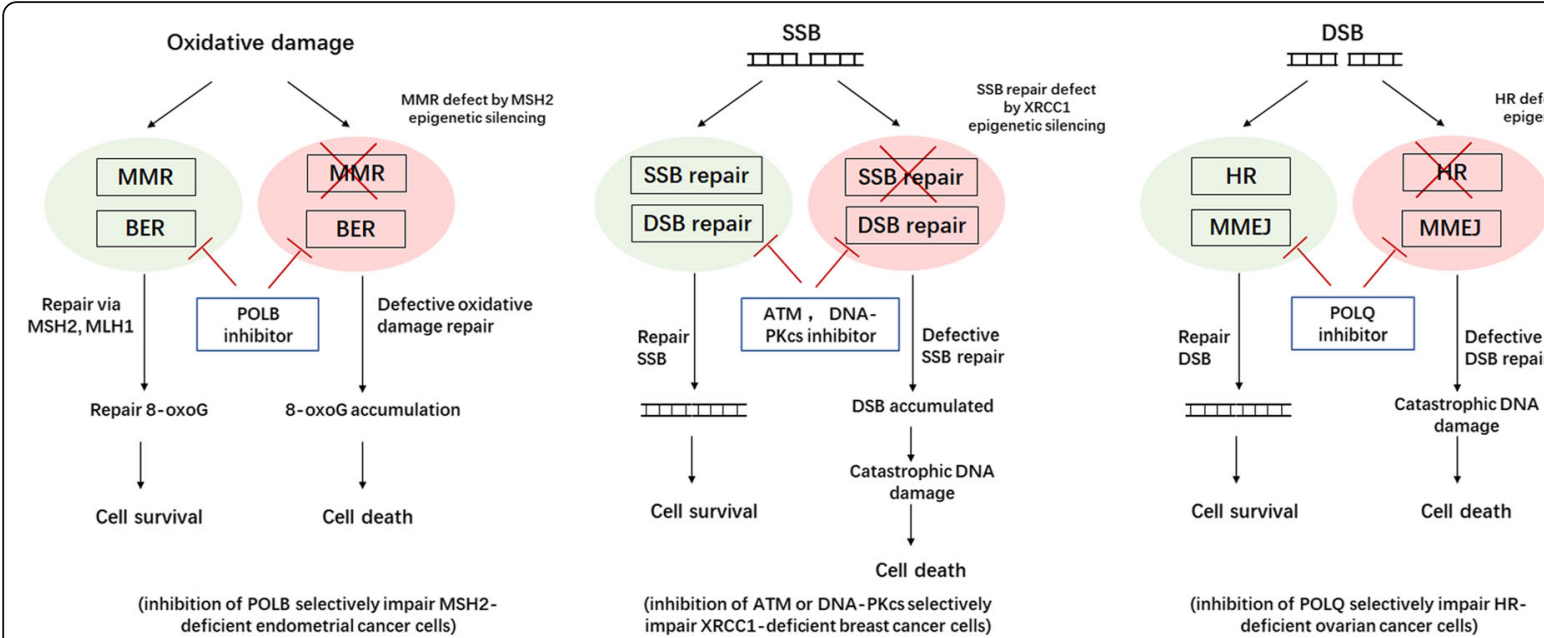

Fig. 2 Synthetic lethality based on epigenetic defects. A. Synthetic lethality induced by combined BER inhibitor and epigenetic inactivation of MMR (inhibition of POLB selectively impair MSH2-deficient endometrial cancer cells). B. Synthetic lethality induced by combined DSB repair inhibitor and epigenetic inactivation of SSB repair (inhibition of ATM or DNA-PKcs selectively impair XRCC1-deficient breast cancer cells). C. Synthetic lethality induced by combined MMEJ repair inhibitor and epigenetic inactivation of HR repair (inhibition of POLQ selectively impair HRdeficient ovarian cancer cells). BER, base excision repair; MMR, mismatch repair; POLB, polymerase theta; SSBs, single-strand breaks; DSBs, doublestrand breaks; HR, homologous recombination repair; MMEJ, microhomology mediated end joining; POLQ, polymerase theta

BRCA1 in another allele [175, 176]. MGMT is mutated in $17.5 \%$ and methylated in $44 \%$ of human esophageal squamous cell carcinoma [177, 178]. Mutation of MGMT is very rare in CRC, while the methylation rate is $40 \%[179,180]$. WRN is frequently methylated in various cancers, while is rarely mutated $[118,181]$. DNA methylation may be served as 'second hit' for carcinogenesis in hereditary cancer, or served as 'first hit' or both 'first and second hit' in sporadic cancer. Combination of aberrant genetic and epigenetic changes of DDR may be more efficient for synthetic lethal therapy.

\section{Conclusion and future perspective}

The successful development of PARPi for BRCA mutant cancers provides proof-of-concept that synthetic lethality interactions can be translated into cancer therapies. A number of lessons can be learned from the discovery and the development of the PARPi in BRCA defect synthetic lethality. Such as, PARPi resistance has been widely reported in clinic, and certain percentage of patients with wild-type BRCA can still benefit from PARPi treatment. This may be explained by unknown of methylation status of BRCAs and defects of other DDR and related genes. The major issue of synthetic lethality therapy is to find good biomarkers and these markers can be used to stratify patients. Ideally, the design and interpretation of clinical trials based on synthetic lethality interactions should be based on the biological hypothesis and robust preclinical data. Therapeutic successes obtained with synthetic lethality demonstrate that DNA repair can be considered as a therapeutic target. Moreover, the concept of synthetic lethality could be extended to interactions between DNA repair deficiencies and other cell signaling abnormalities, such as aberrant genetic/epigenetic changes induced loss-offunction in tumor suppressors. Cell culture based screening approaches, patient-derived xenografts and genetically engineered mouse models of cancer will probably remain essential for uncovering synthetic lethal interactions between genomic/epigenomic lesions and selective inhibition of individual cell cycle regulators. Novel treatment modalities that can target multiple components of the same pathway may help to achieve a more sustained therapeutic benefit.

DDR pathways are the fundamental basis for maintenance of normal cells and, unfortunately, not unique to cancer. Thus, the challenge facing the efficiency of DDR inhibitors is the issue of predictive biomarkers. Some genomic/epigenomic alterations of DDR molecules are known in cancers, and some of them have been proven to be effective and specific targets for certain cancer types. Platinum-based agents could be used as mediators leading the cell to a synthetic lethality favorable for DDR-targeting agents. In addition to PARP inhibitors, new inhibitors that interfere with the activities of important genes and enzymes of the DNA damage repair pathways could also be used for the same purposes. As evolving drug resistance is inevitable until complete tumor ablation is achieved, combined targeting therapies are required. Combination of PARP inhibitors and other DDR inhibitors also have great potential synthetic lethality efficiency. Synthetic lethality only occurs when the primary pathway is defective and the backup rescue pathway is repressed. It is also important to identify 
synthetic rescue pathways and develop strategies to block these before therapeutic resistance develops. It is clear that while drugging DNA repair is still in its infancy, there is enormous potential to this approach because it will be applicable to many other malignancies besides those with BRCA1/2 mutations. One of the biggest problems of synthetic lethality is how to identify biallele inactivated DDR markers in human tissue samples.

As epigenetic abnormalities are apparent in the early stage of carcinogenesis and premalignant status, we may be able to develop strategies for cancer prevention. While the major issue of cancer epigenomes is technique limitation. Genetic/epigenetic heterogeneity is another major issue of targeting therapy. Intratumor heterogeneity may explain the difficulties encountered in the validation of oncology biomarkers and prediction of therapeutic resistance owing to sampling bias. Ideally, we could always target druggable trunk mutations/aberrant epigenetic changes, and then add drugs to target emerging subclones. The tumor environment may represent as much as $90 \%$ of some tumor samples. Epigenetic modifications are dynamic and responsive to environmental pressures, and they may reflect the potential of the tumor to respond to an environmental or therapeutic pressure. With the development of new techniques, combined detection of both genetic and epigenetic markers will hopefully improve the efficiencies of targeting therapy in human cancer.

\section{Abbreviations \\ SSBs: Single-strand breaks; DSBs: Double-strand breaks; ROS: Reactive oxygen species; DDR: DNA damage repair/response; BER: Base excision repair; NER: Nucleotide excision repair; HR: Homologous recombination repair; NHEJ: Non-homologous end joining repair; MMR: Mismatch repair; MMEJ: Microhomology mediated end joining; ssDNA: Single-stranded DNA; RPA: Replication protein A; siRNA: Small interfering RNA; ATM: Ataxia Telangiectasia Mutated; ATR: Ataxia Telangiectasia and Rad3 related; Chk1: Checkpoint kinase 1; Chk2: Checkpoint kinase2; PARPi: PARP inhibitors; $\beta-N A D+$ : $\beta$-nicotinamide adenine dinucleotide.; RECIST: Response Evaluation Criteria in Solid Tumors; DAISY: Data mining synthetic lethality identification pipeline; SDL: Synthetic dosage lethal; WEE1i: Wee1 inhibitor; IPMN: Intraductal papillary mucinous neoplasms; CRC: Colorectal cancer; NSCLC: Non-small cell lung cancer; XRCC1: X-ray repair cross-complementing gene 1; AML: Acute myeloid leukemia; MSI: Microsatellite instability; HPNC C: Hereditary non-polyposis colorectal cancer; HCC: Hepatocellular carcinoma; ESCC: Esophageal squamous cell carcinoma; LOH: Loss of heterozygosity; POLB: Polymerase theta; POLQ: Polymerase theta}

\section{Acknowledgements}

Not applicable.

\section{Authors' contributions}

AG drafted the manuscript. MG designed and revised the manuscript. The authors read and approved the final manuscript.

\section{Funding}

This work was supported by grants from National Key Research and Development Programme of China (2018YFA0208902, 2020YFC2002705); National Science Foundation of China (NSFC No.U1604281, 81672138); Beijing Science Foundation of China (BJSFC No. 7171008); National Key Scientific Instrument Special Programme of China (Grant No. 2011YQ03013405).

\section{Availability of data and materials}

The material supporting the conclusion of this review has been included within the article.

Ethics approval and consent to participate

Not applicable.

Consent for publication

Not applicable.

\section{Competing interests}

The authors declare that they have no competing interests.

\section{Author details}

${ }^{1}$ Department of Gastroenterology and Hepatology, Chinese PLA General Hospital, \#28 Fuxing Road, Beijing 100853, China. ${ }^{2}$ Henan Key Laboratory for Esophageal Cancer Research, Zhengzhou University, 40 Daxue Road,

Zhengzhou 450052, Henan, China. ${ }^{3}$ State Key Laboratory of Kidney Diseases, Chinese PLA General Hospital, \#28 Fuxing Road, Beijing 100853, China.

Received: 26 July 2020 Accepted: 4 September 2020

Published online: 15 September 2020

\section{References}

1. Hoeijmakers JH. DNA damage, aging, and cancer. N Engl J Med. 2009; 361(15):1475-85.

2. Ciccia A, Elledge SJ. The DNA damage response: making it safe to play with knives. Mol Cell. 2010;40(2):179-204.

3. David SS, O'Shea VL, Kundu S. Base-excision repair of oxidative DNA damage. Nature. 2007;447(7147):941-50.

4. Cleaver JE, Lam ET, Revet I. Disorders of nucleotide excision repair: the genetic and molecular basis of heterogeneity. Nat Rev Genet. 2009;10(11): 756-68.

5. Lieber MR. NHEJ and its backup pathways in chromosomal translocations. Nat Struct Mol Biol. 2010;17(4):393-5.

6. Gao D, Herman JG, Guo M. The clinical value of aberrant epigenetic changes of DNA damage repair genes in human cancer. Oncotarget. 2016; 7(24):37331-46.

7. Lord CJ, Ashworth A. The DNA damage response and cancer therapy. Nature. 2012;481(7381):287-94.

8. Rode A, Maass KK, Willmund KV, Lichter P, Ernst A. Chromothripsis in cancer cells: An update. Int J Cancer. 2016;138(10):2322-33.

9. Nickoloff JA, Jones D, Lee SH, Williamson EA, Hromas R. Drugging the cancers addicted to DNA repair. J Natl Cancer Inst. 2017;109(11):djx059.

10. Higgins GS, Boulton SJ. Beyond PARP-POL $\theta$ as an anticancer target. Science. 2018:359(6381):1217-8.

11. Kaelin WG Jr. The concept of synthetic lethality in the context of anticancer therapy. Nat Rev Cancer. 2005;5(9):689-98.

12. Farmer H, McCabe N, Lord CJ, Tutt AN, Johnson DA, Richardson TB, et al. Targeting the DNA repair defect in BRCA mutant cells as a therapeutic strategy. Nature. 2005;434(7035):917-21.

13. Bryant HE, Schultz N, Thomas HD, Parker KM, Flower D, Lopez E, et al. Specific killing of BRCA2-deficient tumours with inhibitors of poly (ADPribose) polymerase. Nature. 2005:434(7035):913-7.

14. Lord CJ, Ashworth A. BRCAness revisited. Nat Rev Cancer. 2016;16(2):110-20.

15. Huang A, Garraway LA, Ashworth A, Weber B. Synthetic lethality as an engine for cancer drug target discovery. Nat Rev Drug Discov. 2020;19(1): 23-38.

16. Gourley C, Balmaña J, Ledermann JA, Serra V, Dent R, Loibl S, et al. Moving from poly (ADP-ribose) polymerase inhibition to targeting DNA repair and DNA damage response in cancer therapy. J Clin Oncol. 2019;37(25):2257-69.

17. Visconti R, Della Monica R, Grieco D. Sustaining the spindle assembly checkpoint to improve cancer therapy. Mol Cell Oncol. 2016;3(1):e1046583.

18. Kastan MB, Bartek J. Cell-cycle checkpoints and cancer. Nature. 2004; 432(7015):316-23.

19. Bartek J, Lukas J. DNA damage checkpoints: from initiation to recovery or adaptation. Curr Opin Cell Biol. 2007;19(2):238-45.

20. Matsuoka S, Huang M, Elledge SJ. Linkage of ATM to cell cycle regulation by the Chk2 protein kinase. Science. 1998;282(5395):1893-7. 
21. Falck J, Mailand N, Syljuåsen RG, Bartek J, Lukas J. The ATM-Chk2-Cdc25A checkpoint pathway guards against radioresistant DNA synthesis. Nature. 2001;410(6830):842-7.

22. Errico A, Costanzo V. Mechanisms of replication fork protection: a safeguard for genome stability. Crit Rev Biochem Mol Biol. 2012;47(3):222-35.

23. Mailand N, Falck J, Lukas C, Syljuâsen RG, Welcker M, Bartek J, et al. Rapid destruction of human Cdc25A in response to DNA damage. Science. 2000; 288(5470):1425-9.

24. Nigg EA. Mitotic kinases as regulators of cell division and its checkpoints. Nat Rev Mol Cell Biol. 2001;2(1):21-32

25. Vitale I, Galluzzi L, Castedo M, Kroemer G. Mitotic catastrophe: a mechanism for avoiding genomic instability. Nat Rev Mol Cell Biol. 2011;12(6):385-92.

26. Hartwell LH, Szankasi P, Roberts CJ, Murray AW, Friend SH. Integrating genetic approaches into the discovery of anticancer drugs. Science. 1997; 278(5340):1064-8.

27. Lord CJ, Tutt AN, Ashworth A. Synthetic lethality and cancer therapy: lessons learned from the development of PARP inhibitors. Annu Rev Med. 2015;66:455-70.

28. Gelmon KA, Tischkowitz M, Mackay H, Swenerton K, Robidoux A, Tonkin K et al. Olaparib in patients with recurrent high-grade serous or poorly differentiated ovarian carcinoma or triple-negative breast cancer: a phase 2, multicentre, open-label, non-randomised study. Lancet Oncol. 2011;12(9): 852-61.

29. Kaufman B, Shapira-Frommer R, Schmutzler RK, Audeh MW, Friedlander M, Balmaña J, et al. Olaparib monotherapy in patients with advanced cancer and a germline BRCA1/2 mutation. J Clin Oncol. 2015;33(3):244-50.

30. Mateo J, Carreira S, Sandhu S, Miranda S, Mossop H, Perez-Lopez R, et al. DNA-repair defects and Olaparib in metastatic prostate cancer. N Engl J Med. 2015;373(18):1697-708.

31. Jordheim LP, Barakat KH, Heinrich-Balard L, Matera EL, Cros-Perrial E, Bouledrak K, et al. Small molecule inhibitors of ERCC1-XPF protein-protein interaction synergize alkylating agents in cancer cells. Mol Pharmacol. 2013; 84(1):12-24

32. Goldstein LJ, Gurtler J, Del Prete SA, Tjulandin S, Semiglazov VF, Bayever E, et al. Trabectedin as a single-agent treatment of advanced breast cancer after anthracycline and taxane treatment: a multicenter, randomized, phase II study comparing 2 administration regimens. Clin Breast Cancer. 2014; 14(6):396-404.

33. Goodwin JF, Knudsen KE. Beyond DNA repair: DNA-PK function in cancer. Cancer Discov. 2014:4(10):1126-39.

34. Biddlestone-Thorpe L, Sajjad M, Rosenberg E, Beckta JM, Valerie NC, Tokarz $M$, et al. ATM kinase inhibition preferentially sensitizes p53-mutant glioma to ionizing radiation. Clin Cancer Res. 2013;19(12):3189-200.

35. Batey MA, Zhao Y, Kyle S, Richardson C, Slade A, Martin NM, et al. Preclinical evaluation of a novel ATM inhibitor, KU59403, in vitro and in vivo in p53 functional and dysfunctional models of human cancer. Mol Cancer Ther. 2013;12(6):959-67.

36. Gavande NS, VanderVere-Carozza PS, Hinshaw HD, Jalal SI, Sears CR, Pawelczak KS, et al. DNA repair targeted therapy: the past or future of cancer treatment? Pharmacol Ther. 2016;160:65-83.

37. Mohni KN, Kavanaugh GM, Cortez D. ATR pathway inhibition is synthetically lethal in cancer cells with ERCC1 deficiency. Cancer Res. 2014;74(10):2835-45.

38. Kwok M, Davies N, Agathanggelou A, Smith E, Petermann E, Yates E, et al. Synthetic lethality in chronic lymphocytic leukaemia with DNA damage response defects by targeting the ATR pathway. Lancet. 2015; 385 Suppl 1:S58.

39. Williamson CT, Miller R, Pemberton HN, Jones SE, Campbell J, Konde A, et al. ATR inhibitors as a synthetic lethal therapy for tumours deficient in ARID1A. Nat Commun. 2016:7:13837.

40. Huntoon CJ, Flatten KS, Wahner Hendrickson AE, Huehls AM, Sutor SL, Kaufmann SH, et al. ATR inhibition broadly sensitizes ovarian cancer cells to chemotherapy independent of BRCA status. Cancer Res. 2013;73(12):3683-91.

41. Gorecki L, Andrs M, Rezacova M, Korabecny J. Discovery of ATR kinase inhibitor berzosertib (VX-970, M6620): clinical candidate for cancer therapy. Pharmacol Ther. 2020;210:107518.

42. Stracker TH, Usui T, Petrini JH. Taking the time to make important decisions: the checkpoint effector kinases Chk1 and Chk2 and the DNA damage response. DNA Repair (Amst). 2009;8(9):1047-54.

43. Bartek J, Lukas J. Chk1 and Chk2 kinases in checkpoint control and cancer. Cancer Cell. 2003;3(5):421-9.
44. Zhang Y, Hunter T. Roles of Chk1 in cell biology and cancer therapy. Int J Cancer. 2014;134(5):1013-23.

45. Menoyo A, Alazzouzi H, Espín E, Armengol M, Yamamoto H, Schwartz S Jr. Somatic mutations in the DNA damage-response genes ATR and CHK1 in sporadic stomach tumors with microsatellite instability. Cancer Res. 2001; 61(21):7727-30

46. Kim CJ, Lee JH, Song JW, Cho YG, Kim SY, Nam SW, et al. Chk1 frameshift mutation in sporadic and hereditary non-polyposis colorectal cancers with microsatellite instability. Eur J Surg Oncol. 2007;33(5):580-5.

47. Rüegg UT, Burgess GM. Staurosporine, K-252 and UCN-01: potent but nonspecific inhibitors of protein kinases. Trends Pharmacol Sci. 1989;10(6): 218-20.

48. Yang SH, Kuo TC, Wu H, Guo JC, Hsu C, Hsu CH, et al. Perspectives on the combination of radiotherapy and targeted therapy with DNA repair inhibitors in the treatment of pancreatic cancer. World J Gastroenterol. 2016;22(32):7275-88.

49. Dent P. Investigational CHK1 inhibitors in early phase clinical trials for the treatment of cancer. Expert Opin Investig Drugs. 2019;28(12):1095-100.

50. Dai Y, Yu C, Singh V, Tang L, Wang Z, Mclnistry R, et al. Pharmacological inhibitors of the mitogen-activated protein kinase (MAPK) kinase/MAPK cascade interact synergistically with UCN-01 to induce mitochondrial dysfunction and apoptosis in human leukemia cells. Cancer Res. 2001;61(13):5106-15.

51. Schmidt M, Rohe A, Platzer C, Najjar A, Erdmann F, Sippl W. Regulation of G2/M transition by inhibition of WEE1 and PKMYT1 kinases. Molecules. 2017; 22(12):2045.

52. Nakanishi M, Ando H, Watanabe N, Kitamura K, Ito K, Okayama H, et al. Identification and characterization of human Wee1B, a new member of the Wee1 family of Cdk-inhibitory kinases. Genes Cells. 2000;5(10):839-47.

53. De Witt Hamer PC, Mir SE, Noske D, Van Noorden CJ, Würdinger T. WEE1 kinase targeting combined with DNA-damaging cancer therapy catalyzes mitotic catastrophe. Clin Cancer Res. 2011;17(13):4200-7.

54. Hirai H, Iwasawa Y, Okada M, Arai T, Nishibata T, Kobayashi M, et al. Smallmolecule inhibition of Wee1 kinase by MK-1775 selectively sensitizes p53deficient tumor cells to DNA-damaging agents. Mol Cancer Ther. 2009;8(11): 2992-3000.

55. Kawamura K, Bahar R, Seimiya M, Chiyo M, Wada A, Okada S, et al. DNA polymerase theta is preferentially expressed in lymphoid tissues and upregulated in human cancers. Int J Cancer. 2004;109(1):9-16.

56. Goullet de Rugy T, Bashkurov M, Datti A, Betous R, Guitton-Sert L, Cazaux C, et al. Excess Pol $\theta$ functions in response to replicative stress in homologous recombination-proficient cancer cells. Biol Open. 2016;5(10):1485-92.

57. Meador CB, Hata AN. Acquired resistance to targeted therapies in NSCLC: updates and evolving insights. Pharmacol Ther. 2020;210:107522.

58. Muller FL, Aquilanti EA, DePinho RA. Collateral lethality: a new therapeutic strategy in oncology. Trends Cancer. 2015;1(3):161-73.

59. Pfister SX, Ashworth A. Marked for death: targeting epigenetic changes in cancer. Nat Rev Drug Discov. 2017:16(4):241-63.

60. McLornan DP, List A, Mufti GJ. Applying synthetic lethality for the selective targeting of cancer. N Engl J Med. 2014;371(18):1725-35.

61. Jerby-Arnon L, Pfetzer N, Waldman YY, McGarry L, James D, Shanks E, et al. Predicting cancer-specific vulnerability via data-driven detection of synthetic lethality. Cell. 2014;158(5):1199-209.

62. Minten EV Y Y DS. DNA repair: translation to the clinic. Clin Oncol (R Coll Radiol). 2019;31(5):303-10.

63. Jariyal H, Weinberg F, Achreja A, Nagarath D, Srivastava A. Synthetic lethality: a step forward for personalized medicine in cancer. Drug Discov Today. 2020;25(2):305-20.

64. Kass EM, Moynahan ME, Jasin M. When genome maintenance goes badly awry. Mol Cell. 2016;62(5):777-87.

65. Morganella S, Alexandrov LB, Glodzik D, Zou X, Davies H, Staaf J, et al. The topography of mutational processes in breast cancer genomes. Nat Commun. 2016:7:11383.

66. McGranahan N, Favero F, de Bruin EC, Birkbak NJ, Szallasi Z, Swanton C. Clonal status of actionable driver events and the timing of mutational processes in cancer evolution. Sci Transl Med. 2015;7(283):283ra54.

67. Nik-Zainal S, Alexandrov LB, Wedge DC, Van Loo P, Greenman CD, Raine K, et al. Mutational processes molding the genomes of 21 breast cancers. Cell. 2012:149(5):979-93.

68. Alexandrov LB, Nik-Zainal S, Siu HC, Leung SY, Stratton MR. A mutational signature in gastric cancer suggests therapeutic strategies. Nat Commun. $2015 ; 6: 8683$ 
69. Alexandrov LB, Nik-Zainal S, Wedge DC, Aparicio SA, Behjati S, Biankin AV, et al. Signatures of mutational processes in human cancer. Nature. 2013; 500(7463):415-21.

70. Patch AM, Christie EL, Etemadmoghadam D, Garsed DW, George J, Fereday $S$, et al. Whole-genome characterization of chemoresistant ovarian cancer. Nature. 2015;521(7553):489-94.

71. Waddell N, Pajic M, Patch AM, Chang DK, Kassahn KS, Bailey P, et al. Whole genomes redefine the mutational landscape of pancreatic cancer. Nature. 2015;518(7540):495-501.

72. Alekseeva IV, Davletgildeeva AT, Arkova OV, Kuznetsov NA, Fedorova OS. The impact of single-nucleotide polymorphisms of human apurinic/ apyrimidinic endonuclease 1 on specific DNA binding and catalysis. Biochimie. 2019;163:73-83.

73. Audebert M, Chevillard S, Levalois C, Gyapay G, Vieillefond A, Klijanienko J, et al. Alterations of the DNA repair gene OGG1 in human clear cell carcinomas of the kidney. Cancer Res. 2000;60(17):4740-4.

74. Starcevic D, Dalal S, Sweasy JB. Is there a link between DNA polymerase beta and cancer? Cell Cycle. 2004;3(8):998-1001.

75. Hoch NC, Hanzlikova H, Rulten SL, Tétreault M, Komulainen E, Ju L, et al. XRCC1 mutation is associated with PARP1 hyperactivation and cerebellar ataxia. Nature. 2017:541(7635):87-91.

76. Sultana R, Abdel-Fatah T, Abbotts R, Hawkes C, Albarakati N, Seedhouse C, et al. Targeting XRCC1 deficiency in breast cancer for personalized therapy. Cancer Res. 2013;73(5):1621-34

77. Shinmura K, Tao H, Goto M, Igarashi H, Taniguchi T, Maekawa M, et al. Inactivating mutations of the human base excision repair gene NEIL1 in gastric cancer. Carcinogenesis. 2004;25(12):2311-7.

78. Zhang R, Jia M, Xue H, Xu Y, Wang M, Zhu M, et al. Genetic variants in ERCC1 and XPC predict survival outcome of non-small cell lung cancer patients treated with platinum-based therapy. Sci Rep. 2017;7(1):10702.

79. Ceccaldi R, O'Connor KW, Mouw KW, Li AY, Matulonis UA, D'Andrea AD, et al. A unique subset of epithelial ovarian cancers with platinum sensitivity and PARP inhibitor resistance. Cancer Res. 2015;75(4):628-34.

80. Mouw KW. DNA repair pathway alterations in bladder cancer. Cancers. 2017; 9(4):80.

81. Liu G, Zhou W, Yeap BY, Su L, Wain JC, Poneros JM, et al. XRCC1 and XPD polymorphisms and esophageal adenocarcinoma risk. Carcinogenesis. 2007; 28(6):1254-8.

82. Miller KL, Karagas MR, Kraft P, Hunter DJ, Catalano PJ, Byler SH, et al. XPA, haplotypes, and risk of basal and squamous cell carcinoma. Carcinogenesis. 2006;27(8):1670-5.

83. Kuismanen SA, Holmberg MT, Salovaara R, de la Chapelle A, Peltomäki $P$. Genetic and epigenetic modification of MLH1 accounts for a major share of microsatellite-unstable colorectal cancers. Am J Pathol. 2000;156(5):1773-9.

84. Martin SA, McCabe N, Mullarkey M, Cummins R, Burgess DJ, Nakabeppu Y, et al. DNA polymerases as potential therapeutic targets for cancers deficient in the DNA mismatch repair proteins MSH2 or MLH1. Cancer Cell. 2010; 17(3):235-48.

85. Lynch HT, Snyder CL, Shaw TG, Heinen CD, Hitchins MP. Milestones of Lynch syndrome: 1895-2015. Nat Rev Cancer. 2015;15(3):181-94.

86. Kawahara N, Ogawa K, Nagayasu M, Kimura M, Sasaki Y, Kobayashi H. Candidate synthetic lethality partners to PARP inhibitors in the treatment of ovarian clear cell cancer. Biomedical Rep. 2017:7(5):391-9.

87. Kim G, Ison G, McKee AE, Zhang H, Tang S, Gwise T, et al. FDA approval summary: Olaparib Monotherapy in patients with deleterious Germline BRCA-mutated advanced ovarian cancer treated with three or more lines of chemotherapy. Clin Cancer Res. 2015;21(19):4257-61.

88. Sultana R, McNeill DR, Abbotts R, Mohammed MZ, Zdzienicka MZ, Qutob H, et al. Synthetic lethal targeting of DNA double-strand break repair deficient cells by human apurinic/apyrimidinic endonuclease inhibitors. Int J Cancer. 2012;131(10):2433-44.

89. Albarakati N, Abdel-Fatah TM, Doherty R, Russell R, Agarwal D, Moseley P, et al. Targeting BRCA1-BER deficient breast cancer by ATM or DNA-PKCS blockade either alone or in combination with cisplatin for personalized therapy. Mol Oncol. 2015;9(1):204-17.

90. Song H, Dicks E, Ramus SJ, Tyrer JP, Intermaggio MP, Hayward J, et al. Contribution of Germline mutations in the RAD51B, RAD51C, and RAD51D genes to ovarian cancer in the population. J Clin Oncol. 2015;33(26):2901-7.

91. Antoniou AC, Casadei S, Heikkinen T, Barrowdale D, Pylkäs K, Roberts J, et al Breast-cancer risk in families with mutations in PALB2. N Engl J Med. 2014; 371(6):497-506.
92. Dedes KJ, Wilkerson PM, Wetterskog D, Weigelt B, Ashworth A, Reis-Filho JS. Synthetic lethality of PARP inhibition in cancers lacking BRCA1 and BRCA2 mutations. Cell Cycle. 2011;10(8):1192-9.

93. Jiao L, Hassan MM, Bondy ML, Wolff RA, Evans DB, Abbruzzese JL, et al. XRCC2 and XRCC3 gene polymorphism and risk of pancreatic cancer. Am J Gastroenterol. 2008;103(2):360-7.

94. Dietlein F, Thelen L, Jokic M, Jachimowicz RD, Ivan L, Knittel G, et al. A functional cancer genomics screen identifies a druggable synthetic lethal interaction between MSH3 and PRKDC. Cancer Discov. 2014;4(5):592-605.

95. Mathew CG. Fanconi anaemia genes and susceptibility to cancer. Oncogene. 2006;25(43):5875-84.

96. McCabe N, Turner NC, Lord CJ, Kluzek K, Bialkowska A, Swift S, et al. Deficiency in the repair of DNA damage by homologous recombination and sensitivity to poly (ADP-ribose) polymerase inhibition. Cancer Res. 2006; 66(16):8109-15.

97. Long XD, Zhao D, Wang C, Huang XY, Yao JG, Ma Y, et al. Genetic polymorphisms in DNA repair genes XRCC4 and XRCC5 and aflatoxin B1related hepatocellular carcinoma. Epidimiology. 2013;24(5):671-81.

98. Tseng RC, Hsieh FJ, Shih CM, Hsu HS, Chen CY, Wang YC. Lung cancer susceptibility and prognosis associated with polymorphisms in the nonhomologous end-joining pathway genes: a multiple genotypephenotype study. Cancer. 2009;115(13):2939-48.

99. Czyż M, Toma M, Gajos-Michniewicz A, Majchrzak K, Hoser G, Szemraj J, et al. PARP1 inhibitor olaparib (Lynparza) exerts synthetic lethal effect against ligase 4-deficient melanomas. Oncotarget. 2016;7(46):75551-60.

100. Bukhari AB, Lewis CW, Pearce JJ, Luong D, Chan GK, Gamper AM. Inhibiting Wee1 and ATR kinases produces tumor-selective synthetic lethality and suppresses metastasis. J Clin Invest. 2019;129(3):1329-44.

101. Zighelboim I, Ali S, Lankes HA, Backes F, Moore K, Mutch D, et al. Assessing the prognostic role of ATR mutation in endometrioid endometrial cancer: An NRG oncology/gynecologic oncology group study. Gynecol Oncol. 2015; 138(3):614-9.

102. Heikkinen K, Mansikka V, Karppinen SM, Rapakko K, Winqvist R. Mutation analysis of the ATR gene in breast and ovarian cancer families. Breast Cancer Res. 2005;7(4):R495-501.

103. Kantidze OL, Velichko AK, Luzhin AV, Petrova NV, Razin SV. Synthetically lethal interactions of ATM, ATR, and DNA-PKcs. Trends in cancer. 2018;4(11): 755-68.

104. Ding L, Getz G, Wheeler DA, Mardis ER, McLellan MD, Cibulskis K, et al. Somatic mutations affect key pathways in lung adenocarcinoma. Nature. 2008:455(7216):1069-75.

105. Joshi PM, Sutor SL, Huntoon CJ, Karnitz LM. Ovarian cancer-associated mutations disable catalytic activity of CDK12, a kinase that promotes homologous recombination repair and resistance to cisplatin and poly (ADP-ribose) polymerase inhibitors. J Biol Chem. 2014;289(13):9247-53.

106. Peña-Llopis S, Vega-Rubín-de-Celis S, Liao A, Leng N, Pavía-Jiménez A, Wang $S$, et al. BAP1 loss defines a new class of renal cell carcinoma. Nat Genet. 2012;44(7):751-9.

107. Aning OA, Cheok CF. Drugging in the absence of p53. J Mol Cell Biol. 2019; 11(3):255-64.

108. Gadhikar MA, Sciuto MR, Alves MV, Pickering CR, Osman AA, Neskey DM, et al. Chk1/2 inhibition overcomes the cisplatin resistance of head and neck cancer cells secondary to the loss of functional p53. Mol Cancer Ther. 2013; 12(9):1860-73.

109. Dedes KJ, Wetterskog D, Mendes-Pereira AM, Natrajan R, Lambros MB, Geyer FC, et al. PTEN deficiency in endometrioid endometrial adenocarcinomas predicts sensitivity to PARP inhibitors. Sci Transl Med. 2010;2(53):53ra75.

110. Guo M, Ren J, House MG, Qi Y, Brock MV, Herman JG. Accumulation of promoter methylation suggests epigenetic progression in squamous cell carcinoma of the esophagus. Clin Cancer Res. 2006:12(15):4515-22.

111. Yan W, Herman JG, Guo M. Epigenome-based personalized medicine in human cancer. Epigenomics. 2016;8(1):119-33.

112. Guo M, Peng Y, Gao A, Du C, Herman JG. Epigenetic heterogeneity in cancer. Biomark Res. 2019;7:23.

113. Ma K, Cao B, Guo M. The detective, prognostic, and predictive value of DNA methylation in human esophageal squamous cell carcinoma. Clin Epigenetics. 2016:8:43

114. Acunzo M, Romano G, Wernicke D, Croce CM. MicroRNA and cancer--a brief overview. Adv Biol Regul. 2015;57:1-9.

115. Bhan A, Soleimani M, Mandal SS. Long noncoding RNA and cancer: a new paradigm. Cancer Res. 2017;77(15):3965-81. 
116. Srinivasan G, Williamson EA, Kong K, Jaiswal AS, Huang G, Kim HS, et al. MiR223-3p promotes synthetic lethality in BRCA1-deficient cancers. Proc Natl Acad Sci U S A. 2019;116(35):17438-43.

117. House MG, Guo M, lacobuzio-Donahue C, Herman JG. Molecular progression of promoter methylation in intraductal papillary mucinous neoplasms (IPMN) of the pancreas. Carcinogenesis. 2003;24(2):193-8.

118. Agrelo R, Cheng WH, Setien F, Ropero S, Espada J, Fraga MF, et al. Epigenetic inactivation of the premature aging Werner syndrome gene in human cancer. Proc Natl Acad Sci U S A. 2006;103(23):8822-7.

119. Nogales V, Reinhold WC, Varma S, Martinez-Cardus A, Moutinho C, Moran S, et al. Epigenetic inactivation of the putative DNA/RNA helicase SLFN11 in human cancer confers resistance to platinum drugs. Oncotarget. 2016;7(3):3084-97.

120. He T, Zhang M, Zheng R, Zheng S, Linghu E, Herman JG, et al. Methylation of SLFN1 1 is a marker of poor prognosis and cisplatin resistance in colorectal cancer. Epigenomics. 2017;9(6):849-62.

121. Peng $Y$, Wang $L$, Wu L, Zhang L, Nie G, Guo M. Methylation of SLFN11 promotes gastric cancer growth and increases gastric cancer cell resistance to cisplatin. J Cancer. 2019;10(24):6124-34.

122. Li Y, Yang Y, Lu Y, Herman JG, Brock MV, Zhao P, et al. Predictive value of CHFR and MLH1 methylation in human gastric cancer. Gastric Cancer. 2015;18(2):280-7.

123. Wang $P$, Tang JT, Peng YS, Chen XY, Zhang YJ, Fang JY. XRCC1 downregulated through promoter hypermethylation is involved in human gastric carcinogenesis. J Dig Dis. 2010;11(6):343-51.

124. Howard JH, Frolov A, Tzeng CW, Stewart A, Midzak A, Majmundar A, et al. Epigenetic downregulation of the DNA repair gene MED1/MBD4 in colorectal and ovarian cancer. Cancer Biol Ther. 2009;8(1):94-100.

125. Chen HY, Shao CJ, Chen FR, Kwan AL, Chen ZP. Role of ERCC1 promoter hypermethylation in drug resistance to cisplatin in human gliomas. Int J Cancer. 2010;126(8):1944-54.

126. Wu YH, Tsai Chang JH, Cheng YW, Wu TC, Chen CY, Lee H. Xeroderma pigmentosum group $C$ gene expression is predominantly regulated by promoter hypermethylation and contributes to p53 mutation in lung cancers. Oncogene. 2007;26(33):4761-73.

127. Yang J, Xu Z, Li J, Zhang R, Zhang G, Ji H, et al. XPC epigenetic silence coupled with p53 alteration has a significant impact on bladder cancer outcome. J Urol. 2010;184(1):336-43.

128. Sabatino MA, Marabese M, Ganzinelli M, Caiola E, Geroni C, Broggini M. Down-regulation of the nucleotide excision repair gene XPG as a new mechanism of drug resistance in human and murine cancer cells. Mol Cancer. 2010;9:259.

129. Lee MN, Tseng RC, Hsu HS, Chen JY, Tzao C, Ho WL, et al. Epigenetic inactivation of the chromosomal stability control genes BRCA1, BRCA2, and XRCC5 in non-small cell lung cancer. Clin Cancer Res. 2007;13(3):832-8.

130. Esteller M, Garcia-Foncillas J, Andion E, Goodman SN, Hidalgo OF, Vanaclocha $V$, et al. Inactivation of the DNA-repair gene MGMT and the clinical response of gliomas to alkylating agents. N Engl J Med. 2000; 343(19):1350-4.

131. Yu W, Zhang L, Wei Q, Shao A. O (6)-methylguanine-DNA methyltransferase (MGMT): challenges and new opportunities in Glioma chemotherapy. Front Oncol. 2019;9:1547.

132. Zhao H, Li J, Li X, Han C, Zhang Y, Zheng L, et al. Silencing GPX3 expression promotes tumor metastasis in human thyroid cancer. Curr Protein Pept Sci. 2015;16(4):316-21

133. Liu X, Zhang X, Zhan Q, Brock MV, Herman JG, Guo M. CDX2 serves as a Wnt signaling inhibitor and is frequently methylated in lung cancer. Cancer Biol Ther. 2012;13(12):1152-7.

134. Liu Y, Zhang M, He T, Yang W, Wang L, Zhang L, et al. Epigenetic silencing of IGFBPL1 promotes esophageal cancer growth by activating PI3K-AKT signaling. Clin Epigenetics. 2020;12(1):22.

135. Li H, Zhang M, Linghu E, Zhou F, Herman JG, Hu L, et al. Epigenetic silencing of TMEM176A activates ERK signaling in human hepatocellular carcinoma. Clin Epigenetics. 2018;10(1):137.

136. Guo Y, Peng Y, Gao D, Zhang M, Yang W, Linghu E, et al. Silencing HOXD10 by promoter region hypermethylation activates ERK signaling in hepatocellular carcinoma. Clin Epigenetics. 2017;9:116.

137. Guo M, Akiyama Y, House MG, Hooker CM, Heath E, Gabrielson E, et al. Hypermethylation of the GATA genes in lung cancer. Clin Cancer Res. 2004; 10(23):7917-24.

138. Guo M, House MG, Akiyama Y, Qi Y, Capagna D, Harmon J, et al. Hypermethylation of the GATA gene family in esophageal cancer. Int J Cancer. 2006;119(9):2078-83.
139. Fu B, Guo M, Wang S, Campagna D, Luo M, Herman JG, et al. Evaluation of GATA-4 and GATA-5 methylation profiles in human pancreatic cancers indicate promoter methylation patterns distinct from other human tumor types. Cancer Biol Ther. 2007;6(10):1546-52.

140. Liu P, Zhou TF, Qiu BA, Yang YX, Zhu YJ, An Y, et al. Methylation-mediated silencing of GATA5 gene suppresses Cholangiocarcinoma cell proliferation and metastasis. Transl Oncol. 2018;11(3):585-92.

141. Yun T, Liu Y, Gao D, Linghu E, Brock MV, Yin D, et al. Methylation of CHFR sensitizes esophageal squamous cell cancer to docetaxel and paclitaxel. Genes Cancer. 2015;6(1-2):38-48.

142. Guo M, Alumkal J, Drachova T, Gao D, Marina SS, Jen J, et al. CHFR methylation strongly correlates with methylation of DNA damage repair and apoptotic pathway genes in non-small cell lung cancer. Discov Med. 2015;19(104):151-8.

143. Dubois F, Bergot E, Zalcman G, Levallet G. RASSF1A, puppeteer of cellular homeostasis, fights tumorigenesis, and metastasis-an updated review. Cell Death Dis. 2019;10(12):928.

144. Jia Y, Yang Y, Brock MV, Zhan Q, Herman JG, Guo M. Epigenetic regulation of DACT2, a key component of the Wnt signalling pathway in human lung cancer. J Pathol. 2013;230(2):194-204.

145. Zhang M, Linghu E, Zhan Q, He T, Cao B, Brock MV, et al. Methylation of DACT2 accelerates esophageal cancer development by activating Wnt signaling. Oncotarget. 2016;7(14):17957-69.

146. Li J, Zhang M, He T, Li H, Cao T, Zheng L, et al. Methylation of DACT2 promotes breast cancer development by activating Wnt signaling. Sci Rep. 2017;7(1):3325.

147. Zhang Y, Fan J, Fan Y, Li L, He X, Xiang Q, et al. The new $6 q 27$ tumor suppressor DACT2, frequently silenced by CpG methylation, sensitizes nasopharyngeal cancer cells to paclitaxel and 5-FU toxicity via $\beta$-catenin/ Cdc25c signaling and G2/M arrest. Clin Epigenetics. 2018;10(1):26.

148. Cao B, Yang W, Jin Y, Zhang M, He T, Zhan Q, et al. Silencing NKD2 by promoter region Hypermethylation promotes esophageal cancer progression by activating Wnt signaling. J Thorac Oncol. 2016;11(11):1912-26.

149. Guo M, Jia Y, Yu Z, House MG, Esteller M, Brock MV, et al. Epigenetic changes associated with neoplasms of the exocrine and endocrine pancreas. Discov Med. 2014;17(92):67-73.

150. Kalachand RD, Stordal B, Madden S, Chandler B, Cunningham J, Goode EL, et al. BRCA1 promoter methylation and clinical outcomes inovarian cancer: an individual patient data meta-analysis. J Natl Cancer Inst. 2020; in press.

151. Herman JG, Umar A, Polyak K, Graff JR, Ahuja N, Issa JP, et al. Incidence and functional consequences of hMLH1 promoter hypermethylation in colorectal carcinoma. Proc Natl Acad Sci U S A. 1998;95(12):6870-5.

152. Nagasaka T, Rhees J, Kloor M, Gebert J, Naomoto Y, Boland CR, et al. Somatic hypermethylation of $\mathrm{MSH} 2$ is a frequent event in Lynch syndrome colorectal cancers. Cancer Res. 2010;70(8):3098-108.

153. Hinrichsen I, Kemp M, Peveling-Oberhag J, Passmann S, Plotz G, Zeuzem S, et al. Promoter methylation of MLH1, PMS2, MSH2 and p16 is a phenomenon of advanced-stage HCCs. PLoS One. 2014;9(1):e84453.

154. Hegi ME, Sciuscio D, Murat A, Levivier M, Stupp R. Epigenetic deregulation of DNA repair and its potential for therapy. Clin Cancer Res. 2009;15(16): 5026-31.

155. Levallet G, Creveuil C, Bekaert L, Péres E, Planchard G, Lecot-Cotigny S, et al. Promoter Hypermethylation of genes encoding for RASSF/hippo pathway members reveals specific alteration pattern in diffuse Gliomas. J Mol Diagn. 2019:21(4):695-704.

156. Yang B, House MG, Guo M, Herman JG, Clark DP. Promoter methylation profiles of tumor suppressor genes in intrahepatic and extrahepatic cholangiocarcinoma. Mod Pathol. 2005;18(3):412-20.

157. Yu Y, Yan W, Liu X, Jia Y, Cao B, Yu Y, et al. DACT2 is frequently methylated in human gastric cancer and methylation of DACT2 activated Wnt signaling Am J Cancer Res. 2014;4(6):710-24.

158. Jia Y, Cao B, Yang Y, Linghu E, Zhan Q, Lu Y, et al. Silencing NKD2 by promoter region hypermethylation promotes gastric cancer invasion and metastasis by up-regulating SOX18 in human gastric cancer. Oncotarget. 2015;6(32):33470-85.

159. Dong Y, Cao B, Zhang M, Han W, Herman JG, Fuks F, et al. Epigenetic silencing of NKD2, a major component of Wnt signaling, promotes breast cancer growth. Oncotarget. 2015:6(26):22126-38.

160. Guo M, Ren J, Brock MV, Herman JG, Carraway HE. Promoter methylation of $\mathrm{HIN}-1$ in the progression to esophageal squamous cancer. Epigenetics. 2008;3(6):336-41. 
161. Yu Y, Yin D, Hoque MO, Cao B, Jia Y, Yang Y, et al. AKT signaling pathway activated by HIN-1 methylation in non-small cell lung cancer. Tumour Biol. 2012;33(2):307-14.

162. Yan W, Wu K, Herman JG, Brock MV, Zhou Y, Lu Y, et al. Epigenetic silencing of DACH1 induces the invasion and metastasis of gastric cancer by activating TGF- $\beta$ signalling. J Cell Mol Med. 2014;18(12):2499-511.

163. Wu L, Herman JG, Brock MV, Wu K, Mao G, Yan W, et al. Silencing DACH1 promotes esophageal cancer growth by inhibiting TGF- $\beta$ signaling. PLoS One. 2014;9(4):e95509.

164. Zhu H, Wu K, Yan W, Hu L, Yuan J, Dong Y, et al. Epigenetic silencing of $\mathrm{DACH} 1$ induces loss of transforming growth factor- $\beta 1$ antiproliferative response in human hepatocellular carcinoma. Hepatology. 2013;58(6):2012-22.

165. Shen H, Laird PW. Interplay between the cancer genome and epigenome. Cell. 2013:153(1):38-55.

166. Ley TJ, Ding L, Walter MJ, McLellan MD, Lamprecht T, Larson DE, et al. DNMT3A mutations in acute myeloid leukemia. N Engl J Med. 2010;363(25): 2424-33.

167. Yan XJ, Xu J, Gu ZH, Pan CM, Lu G, Shen Y, et al. Exome sequencing identifies somatic mutations of DNA methyltransferase gene DNMT3A in acute monocytic leukemia. Nat Genet. 2011;43(4):309-15.

168. Ko M, Huang Y, Jankowska AM, Pape UJ, Tahiliani M, Bandukwala HS, et al. Impaired hydroxylation of 5-methylcytosine in myeloid cancers with mutant TET2. Nature. 2010:468(7325):839-43.

169. Toyota M, Suzuki H. Epigenetic drivers of genetic alterations. Adv Genet. 2010;70:309-23.

170. Esteller M, Toyota M, Sanchez-Cespedes M, Capella G, Peinado MA, Watkins DN, et al. Inactivation of the DNA repair gene O6methylguanine-DNA methyltransferase by promoter hypermethylation is associated with $\mathrm{G}$ to a mutations in K-ras in colorectal tumorigenesis. Cancer Res. 2000;60(9):2368-71.

171. Knudson AG Jr. Mutation and cancer: statistical study of retinoblastoma. Proc Natl Acad Sci U S A. 1971:68(4):820-3.

172. Bellacosa A. Genetic hits and mutation rate in colorectal tumorigenesis: versatility of Knudson's theory and implications for cancer prevention. Genes Chromosomes Cancer. 2003;38(4):382-8.

173. Okugawa Y, Grady WM, Goel A. Epigenetic alterations in colorectal cancer: emerging biomarkers. Gastroenterology. 2015;149(5):1204-25.e12.

174. Chen S, Parmigiani G. Meta-analysis of BRCA1 and BRCA2 penetrance. J Clin Oncol. 2007;25(11):1329-33.

175. Esteller M, Silva JM, Dominguez G, Bonilla F, Matias-Guiu X, Lerma E, et al. Promoter hypermethylation and BRCA1 inactivation in sporadic breast and ovarian tumors. J Natl Cancer Inst. 2000;92(7):564-9.

176. Hu Y, Guo M. Synthetic lethality strategies: Beyond BRCA1/2 mutations in pancreatic cancer. Cancer Sci. 2020;111(9):3111-21.

177. Wang L, Zhu D, Zhang C, Mao X, Wang G, Mitra S, et al. Mutations of O6methylguanine-DNA methyltransferase gene in esophageal cancer tissues from northern China. Int J Cancer. 1997;71(5):719-23.

178. Zhang L, Lu W, Miao X, Xing D, Tan W, Lin D. Inactivation of DNA repair gene O6-methylguanine-DNA methyltransferase by promoter hypermethylation and its relation to p53 mutations in esophageal squamous cell carcinoma. Carcinogenesis. 2003;24(6):1039-44.

179. Belhadj S, Moutinho C, Mur P, Setien F, Llinàs-Arias P, Pérez-Salvia M, et al. Germline variation in O (6)-methylguanine-DNA methyltransferase (MGMT) as cause of hereditary colorectal cancer. Cancer Lett. 2019;447:86-92.

180. Esteller M, Hamilton SR, Burger PC, Baylin SB, Herman JG. Inactivation of the DNA repair gene O6-methylguanine-DNA methyltransferase by promoter hypermethylation is a common event in primary human neoplasia. Cancer Res. 1999:59(4):793-7.

181. Agrelo R, Sutz MA, Setien F, Aldunate F, Esteller M, Da Costa V, et al. A novel Werner syndrome mutation: pharmacological treatment by readthrough of nonsense mutations and epigenetic therapies. Epigenetics. 2015:10(4):329-41.

\section{Publisher's Note}

Springer Nature remains neutral with regard to jurisdictional claims in published maps and institutional affiliations.

\section{Ready to submit your research? Choose BMC and benefit from:}

- fast, convenient online submission

- thorough peer review by experienced researchers in your field

- rapid publication on acceptance

- support for research data, including large and complex data types

- gold Open Access which fosters wider collaboration and increased citations

- maximum visibility for your research: over $100 \mathrm{M}$ website views per year

At BMC, research is always in progress.

Learn more biomedcentral.com/submissions 